\title{
Re-formation of chlorine reservoirs in southern hemisphere polar spring
}

\author{
Jens-Uwe Grooss, ${ }^{1,2}$ R. Bradley Pierce, ${ }^{3}$ Paul J. Crutzen, ${ }^{1}$ William L. Grose, ${ }^{3}$ and
} James M. Russell III ${ }^{4}$

\begin{abstract}
This paper focuses on the recovery of chlorine reservoir species in the lower stratosphere in late Antarctic spring. The investigations are based on measurements from the Halogen Occultation Experiment (HALOE) on board the Upper Atmosphere Research Satellite (UARS) and calculations by the Mainz photochemical box model and the NASA Langley Research Center trajectory model. During late Antarctic spring 1994, HALOE observed high $\mathrm{HCl}$ mixing ratios up to $2.7 \mathrm{ppbv}$ at $20 \mathrm{~km}$ altitude in the ozone-depleted air inside the polar vortex. These values correspond approximately to the sum of all available inorganic chlorine species. In the preceding period of chlorine activation on polar stratospheric clouds (PSCs), the observed $\mathrm{HCl}$ mixing ratios in some cases were below $0.3 \mathrm{ppbv}$. This indicates a fast conversion of active chlorine species into the form of $\mathrm{HCl}$ after PSCs disappear with increasing stratospheric temperatures. Box model calculations are presented that assess the rate of $\mathrm{HCl}$ increase in late spring when heterogeneous chemistry on polar stratospheric clouds becomes insignificant. The calculations were performed along Lagrangian trajectories starting from HALOE measurements in September 1994. Sensitivity calculations are presented regarding uncertainties in input parameters of the calculations. In the vortex edge region, calculated $\mathrm{HCl}$ increase rates are significantly lower compared with HALOE observations. Introducing additional $\mathrm{HCl}$-yielding branches of the reactions of $\mathrm{ClO}$ with $\mathrm{OH}$ and $\mathrm{HO}_{2}$ helps to reduce this discrepancy.
\end{abstract}

\section{Introduction}

It is well established that chlorine compounds are an essential factor for catalytic ozone depletion that leads to the formation of the ozone hole in Antarctica. The understanding of conversions from the passive chlorine reservoirs $(\mathrm{HCl}$, $\left.\mathrm{ClONO}_{2}\right)$ into active forms $\left(\mathrm{Cl}, \mathrm{ClO}, \mathrm{Cl}_{2} \mathrm{O}_{2}\right)$ and back is important to quantify the ozone depletion. In this paper, the reformation of the chlorine reservoirs is investigated. After the chlorine-activating polar stratospheric clouds (PSCs) have evaporated due to the temperature increase in the Antarctic spring, the conversion back to chlorine reservoirs takes place. For low ozone mixing ratios, typical of the Antarctic lower stratosphere in early spring, the rapid formation of $\mathrm{HCl}$ by the reaction $\mathrm{Cl}+\mathrm{CH}_{4}$ is favored over $\mathrm{ClONO}_{2}$ formation via $\mathrm{ClO}+\mathrm{NO}_{2}$, which is more typical in the northern hemisphere [Prather and Jaffe, 1990; Douglass et al., 1995]. This increase of $\mathrm{HCl}$ mixing ratios is observed by

\footnotetext{
${ }^{1}$ Max-Planck-Institut für Chemie, Mainz, Germany

${ }^{2}$ Now at Institut für Stratosphärische Chemie, Forschungszentrum Jülich, Jülich, Germany

${ }^{3}$ NASA Langley Research Center, Hampton, Virginia

${ }^{4}$ Department of Physics, Hampton University, Hampton, Virginia
}

Copyright 1997 by the American Geophysical Union.

Paper number 96JD03505.

0148-0227/97/96JD-03505\$09.00 the Halogen Occultation Experiment (HALOE). For the 1994 Airborne Southern Hemisphere Ozone Experiment (ASHOE) campaign, calculations along middle latitude trajectories of airmasses observed by HALOE have been made and compared successfully with in situ measurements made on the ER-2 aircraft [Pierce et al., this issue]. The same model and similar initialization method are used here to calculate the $\mathrm{HCl}$ increase rate within the Antarctic polar vortex in late spring compared with the increase measured by HALOE.

\section{Observations}

The HALOE instrument, launched in 1991 on the Upper Atmosphere Research Satellite (UARS), is designed to measure important atmospheric trace constituents involved in ozone chemistry. Observations of chemical compounds include ozone $\left(\mathrm{O}_{3}\right)$, water vapor $\left(\mathrm{H}_{2} \mathrm{O}\right)$, methane $\left(\mathrm{CH}_{4}\right)$, hydrogen fluoride (HF), nitrogen oxides (NO and $\mathrm{NO}_{2}$ ), and hydrogen chloride $(\mathrm{HCl})$ at sunrise and sunset [Russell et al., 1993a]. The data presented here were obtained from software version 17 of the retrieval algorithm. The accuracy of the HALOE data as derived from correlative measurements at the altitude considered here $(\approx 20 \mathrm{~km})$ is typically 5-10\% for ozone [Brühl et al., 1996] and 15-20\% for $\mathrm{HCl}$ [Russell et al., 1996]. HALOE extensively sampled the Antarctic polar vortex during mid-September to mid-October 1994. To identify vortex air, $\mathrm{CH}_{4}$ mixing ra- 


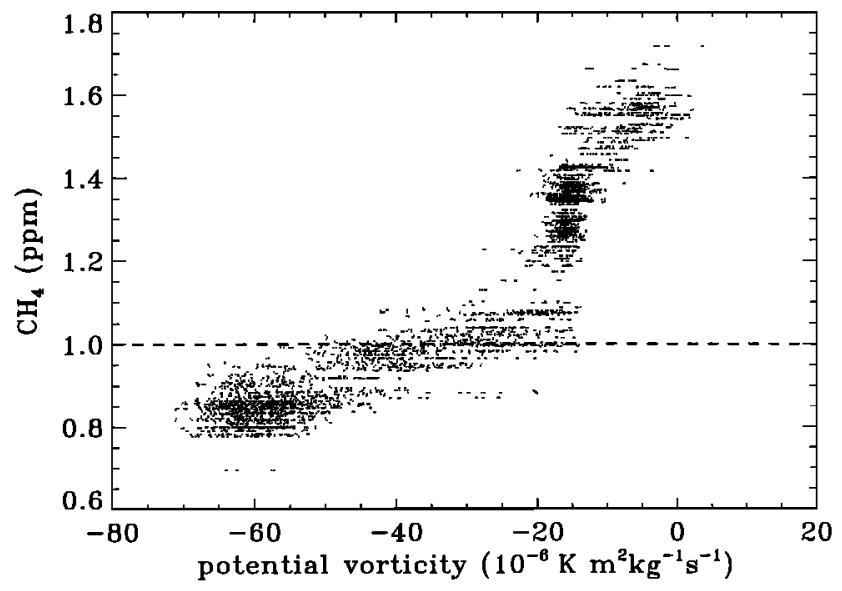

Figure 1. $\mathrm{CH}_{4}$ as a function of UKMO potential vorticity on the $460 \mathrm{~K}$ potential temperature surface between September 24 and October 18, 1994. On this isentropic level, airmasses with a $\mathrm{CH}_{4}$ mixing ratio below $1.0 \mathrm{ppmv}$ (dashed line) are assumed to be inside the polar vortex.

tios measured by HALOE were used. Diabatic descent of air inside the polar vortex results in lower $\mathrm{CH}_{4}$ mixing ratios on a specific isentropic surface than for air parcels outside, indicating their origin from higher altitudes [Russell et al., 1993b]. Figure 1 shows HALOE $\mathrm{CH}_{4}$ mixing ratios in October as a function of potential vorticity (PV) on the $460 \mathrm{~K}$ isentropic surface, derived from United Kingdom Meteorological Office (UKMO) wind and temperature data. Airmasses with high negative PV, located inside the vortex, are correlated with low $\mathrm{CH}_{4}$ mixing ratios. On the chosen potential temperature level of $460 \mathrm{~K}$, airmasses with a $\mathrm{CH}_{4}$ mixing ratio below $1.0 \mathrm{ppmv}$ are assumed to be inside the vortex.

HALOE generally measured very low $\mathrm{O}_{3}$ mixing ratios (down to $0.1 \mathrm{ppmv}$ ) and low mixing ratios of $\mathrm{NO}_{\mathrm{x}}(:=\mathrm{NO}+$ $\mathrm{NO}_{2}$ ) down to $0.15 \mathrm{ppbv}$ inside the vortex. The re-formation of the chlorine reservoir $\mathrm{HCl}$ can be seen in the HALOE measurements. A time series of vortex $\mathrm{HCl}$ mixing ratios from September 11 to October 18 on the $460 \mathrm{~K}$ potential temperature level is displayed in Figure 2. Very low $\mathrm{HCl}$ mixing ratios below $0.3 \mathrm{ppbv}$ are measured within the vortex in mid-September, increasing to $2.7 \mathrm{ppbv}$ within 1 month. During this period, the $\mathrm{HCl}$ mixing ratio outside the vortex $\left(\mathrm{CH}_{4}>1.2 \mathrm{ppmv}\right)$ stayed almost constant at about $1.0 \mathrm{ppbv}$ (not shown). This indicates the typical high chlorine activation within the vortex in early spring followed by an almost complete conversion of active chlorine species into $\mathrm{HCl}$, because the observed final $\mathrm{HCl}$ mixing ratios correspond to the mixing ratio of total inorganic chlorine $\mathrm{Cl}_{\mathrm{y}}\left(:=\mathrm{HCl}+\mathrm{ClONO}{ }_{2}+\mathrm{HOCl}+\mathrm{Cl}+\mathrm{ClO}+2 \cdot \mathrm{Cl}_{2} \mathrm{O}_{2}\right)$ at this altitude. Thus, the other chlorine reservoir species $\mathrm{ClONO}_{2}$ was also converted into $\mathrm{HCl}$. In the figure, different ozone mixing ratios are plotted with different symbols indicating that the $\mathrm{HCl}$ mixing ratios increase faster for low ozone mixing ratios. The $\mathrm{HCl}$ increase rate is estimated by a linear fit to the HALOE data in each ozone mixing ratio bin (see legend in Figure 2). The time range of the fit (September 24 to October 18) corresponds to that of the fourth ASHOE deployment when trajectory calculations were available. Note however, that this is only an estimate of the increase rate of $\mathrm{HCl}$ mixing ratios since observations grouped within the same ozone mixing ratio bin do not represent the same air parcel but similar airmasses, yet the trend in the data is obvious. The fitting errors of the $\mathrm{HCl}$ increase rate lie between 10 and $15 \%(1 \sigma)$. The accuracy of the HALOE $\mathrm{HCl}$ data is about $15-20 \%$ at this altitude [Russell et al., 1996]. Although the latitude of the HALOE observations changes with time between $56^{\circ} \mathrm{S}$ and $73^{\circ} \mathrm{S}$, the data are comparable since only vortex measurements were chosen. The systematic uncertainty that could arise from the latitude sampling of the HALOE instrument was estimated from simultaneously measured $\mathrm{HF}$ and derived $\mathrm{Cl}_{\mathbf{y}}$ data. On an isentropic level, $\mathrm{Cl}_{y}$ generally increases with latitude. This may overestimate the $\mathrm{HCl}$ increase rate by up to $20 \%$. On the other hand, if the data equatorward of $60^{\circ} \mathrm{S}$ (September 28 to October 1) were left out of the linear fit, the derived $\mathrm{HCl}$ increase rates rose by up to $12 \%$. The overall uncertainty of the derived $\mathrm{HCl}$ increase rate due to data accuracy (20\%), latitude sampling $(20 \%)$ and line fitting error $(15 \%)$ is of the order of $30-40 \%$.

The observed $\mathrm{HCl}$ increase rate is unlikely to be caused by dynamical processes: The diabatic descent inside the vortex or at the vortex edge could transport $\mathrm{HCl}$-rich air down to the $\theta=460 \mathrm{~K}$ level. However, in order to explain the observed $\mathrm{HCl}$ increase rate, diabatic cooling rates of about $6 \mathrm{~K} / \mathrm{d}$ would be needed and the maximum cooling rates are lower by about a factor of 10 , as estimated from calculations at $70 \mathrm{hPa}$ on October 6, 1994 using the Shine radiative heating code [Shine, 1987] and UKMO assimilated temperatures. Furthermore, if one invokes vertical or horizontal transport or mixing as an explanation, one would expect similar trends for $\mathrm{HCl}$ and $\mathrm{HF}$ measurements, but there is

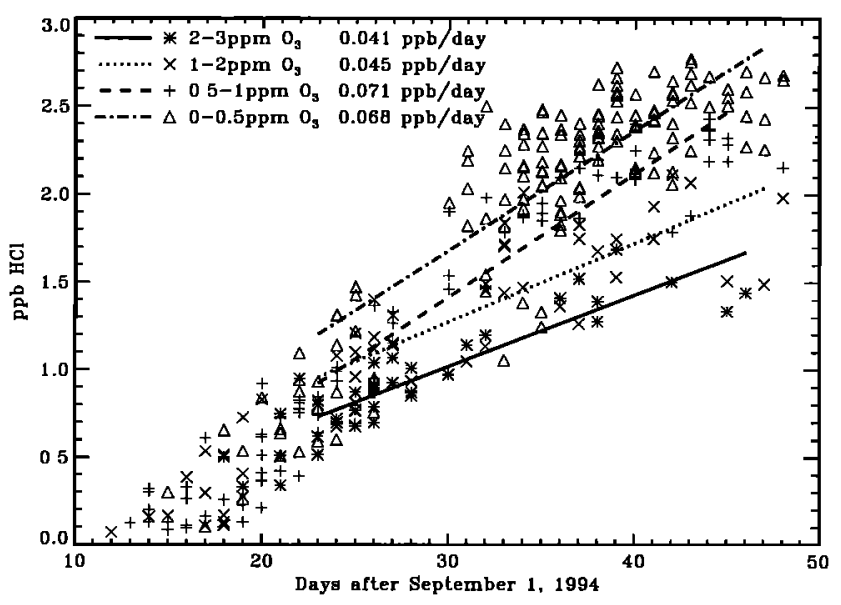

Figure 2. $\mathrm{HCl}$ mixing ratio as a function of time inside the polar vortex as it is measured by HALOE on the $460 \mathrm{~K}$ potential temperature level. The vortex is characterized by $\mathrm{CH}_{4}$ values less than $1.0 \mathrm{ppmv}$ for HALOE sunrise and sunset measurements south of $50^{\circ} \mathrm{S}$. Different ozone mixing ratio intervals are indicated with different symbols. A linear fit to the data for days 23-47 (September 24 to October 18), is shown for each ozone interval. 
no significant trend in the HF data over this time period (not shown). Therefore, the correlation between the $\mathrm{HCl}$ increase rate and ozone suggests a chemical cause.

The observed airmasses show a clear signature of dehydration. Typical $\mathrm{H}_{2} \mathrm{O}$ mixing ratios in the ozone-depleted air $\left(\mathrm{O}_{3}<1\right.$ ppmv) are between 2 and 3 ppmv; a few observations are even slightly below 2 ppmv which is comparable with the observed dehydration in 1987 [Kelly et al., 1989].

\section{Model Descriptions}

Trajectories of the airmasses were calculated by the NASA Langley Research Center trajectory model which uses a fourth order Runge-Kutta scheme using linearly interpolated wind and temperature fields provided by the UKMO analysis [Pierce et al., 1994].

The Mainz photochemical box model uses an implicit numerical integration scheme developed by Gear [1971] with a self-adjusting time step, the commercial package FACSIMILE [Curtis and Sweetenham, 1987], to integrate the chemical equations. The model includes 38 chemical species, a standard reaction scheme with 69 gas phase reactions ( 8 termolecular, 57 bimolecular, 4 thermal decay) including the methane oxidation chain and 22 photolysis reactions. Heterogeneous chemistry on/in liquid ternary $\mathrm{H}_{2} \mathrm{SO}_{4} / \mathrm{HNO}_{3} /$ $\mathrm{H}_{2} \mathrm{O}$ solution aerosols is parametrized from results of a thermodynamic model [Carslaw et al., 1995a,b]. Also, heterogeneous chemistry on crystalline nitric acid trihydrate (NAT) and ice particles is incorporated. Heterogeneous chemistry on sulfuric acid tetrahydrate (SAT) is not incorporated, which is justified since uptake coefficients on SAT are significantly below those on the liquid aerosol [Ravishankara and Hanson, 1996]. Crystalline (ice, NAT, SAT) particles are assumed to form only as temperatures fall below the the ice frost point [Koop et al., 1995] and evaporate as temperatures rise above the corresponding thermodynamic equilibrium temperatures $\left(T_{\mathrm{SAT}}, T_{\mathrm{NAT}}, T_{\mathrm{Ice}}\right)$. The model uses currently recommended kinetic reaction rates [DeMore et al., 1994]. The photolysis rates are calculated by a spherical geometry scheme that was developed by Lary and Pyle [1991]. Integrations of the kinetic reaction equations are performed along an airmass trajectory using temperature, pressure and position information obtained from the trajectory model. For a more detailed description of the models see Pierce et al. [1994], Müller and Crutzen [1993], Müller et al. [1994] and K.S. Carslaw et al. (Uncertainties in reactive uptake coefficients for solid stratospheric particles, 2, Effect on modeled ozone depletion, submitted to Geophysical Research Letters, 1996).

\section{Trajectory Calculations}

Calculations were performed for an ensemble of 63 trajectories that start at the locations of HALOE sunrise measurements in the vortex on the $460 \mathrm{~K}$ potential temperature level around $60^{\circ} \mathrm{S}$ latitude between September 24 and 29, 1994, and that end on October 18, 1994. The error introduced by assuming isentropic trajectories was estimated by comparing the isentropic evolution of all HALOE airmasses between September 24 and October 18, 1994, with a threedimensional model calculation over the same time interval. In these calculations, $95 \%$ of the trajectories stayed within a range of $\sim 12^{\circ}$ in longitude, $\sim 2.5^{\circ}$ in latitude, and $\sim 5 \mathrm{~K}$ in potential temperature, respectively. Thus, diabatic descent is not a significant error source. Furthermore, the prediction of the exact location of the single air parcels is not critical to this study, since no coincidences with other data are used.

\section{Initialization of Chemical Species}

The initialization of all relevant chemical species is of critical importance to get reliable results in the box model calculations. The HALOE experiment provides measurements of $\mathrm{O}_{3}, \mathrm{H}_{2} \mathrm{O}, \mathrm{CH}_{4}, \mathrm{NO}, \mathrm{NO}_{2}, \mathrm{HCl}$ and $\mathrm{HF}$ that were used directly to initialize the box model. The remaining species were determined from a combination of HALOE data, correlations with other data, and monthly climatologies of the latitude-pressure distributions of chemical species obtained by the Mainz two-dimensional (2-D) photochemical model [Gidel et al., 1983; Brühl and Crutzen, 1993; Grooss et al., 1994]. A third-order polynomial fit between total inorganic chlorine $\mathrm{Cl}_{\mathrm{y}}$ and $\mathrm{HF}$ as derived from the 2-D model was used to determine the initialization of $\mathrm{Cl}_{\mathrm{y}}$ from HALOE HF observations [Müller et al., 1996] (e.g. for September 1994 and $65^{\circ} \mathrm{S},\left[\mathrm{Cl}_{\mathrm{y}}\right]=-0.344+6.22 \cdot[\mathrm{HF}]-2.36 \cdot[\mathrm{HF}]^{2}-0.119 \cdot[\mathrm{HF}]^{3}$, where $[\mathrm{HF}]$ and $\left[\mathrm{Cl}_{\mathrm{y}}\right]$ are given in parts per billion by volume, $[\mathrm{HF}]<1.46 \mathrm{ppbv})$. At the $460 \mathrm{~K}$ level within the polar vortex, typical values of $2.7 \mathrm{ppbv} \mathrm{Cl}_{\mathrm{y}}$ were derived from the HALOE data. The initial partitioning within the inorganic chlorine species was derived in the following way. The $\mathrm{HCl}$ mixing ratio was initialized directly from the HALOE measurement. The relative partitioning within $\mathrm{ClOX}\left(:=\mathrm{Cl}_{y}-\right.$ $\mathrm{HCl}$ ), mainly $\mathrm{ClO}$ and $\mathrm{ClONO}_{2}$, that could not be derived from the HALOE measurements was taken from the 2-D model results for the given month at the closest latitude grid point. During Antarctic spring, this relative partitioning was very variable near the vortex edge, and some caution needs to be applied when using the 2-D model results for initialization in regions of large latitudinal gradients due to its coarse latitudinal resolution $\left(10^{\circ}\right)$. On September 15 on the $55 \mathrm{hPa}$ level at $65^{\circ} \mathrm{S}, 92 \%$ of the $\mathrm{ClOX}$ was in the form of $\mathrm{ClONO}_{2}$ corresponding to the $\mathrm{ClONO}_{2}$ collar that was observed in aircraft measurements [Toon et al., 1989], whereas at $75^{\circ} \mathrm{S}$, the partitioning was opposite, only $6 \%$ of the $\mathrm{ClOX}$ being $\mathrm{ClONO}_{2}$. Thus the exact partitioning of the ClOX species is not clear from the 2-D model and is likely to be between the two cases. To account for this problem, two extreme possibilities of initial partitioning within $\mathrm{ClOX}$ were selected: In the reference calculation, the partitioning ratio was taken from the corresponding 2-D latitude (vortex edge), which might be an overestimation of $\mathrm{ClONO}_{2}$. In contrast, sensitivity calculations were performed in which all $\mathrm{ClOX}$ was initialized as $\mathrm{ClO}$ to simulate air inside the vortex core where most of the chlorine was in the active form $\mathrm{ClO}$ and its dimer. The possible range of solutions should lie in between those two extreme cases. 
The odd nitrogen species were initialized using the correlation of $\mathrm{CH}_{4}$ and $\mathrm{NO}_{\mathrm{y}}\left(:=\mathrm{HNO}_{3}+\mathrm{NO}+\mathrm{NO}_{2}+\mathrm{NO}_{3}+\right.$ $2 \cdot \mathrm{N}_{2} \mathrm{O}_{5}+\mathrm{HNO}_{4}+\mathrm{ClONO}_{2}$ ) obtained on ER-2 flights during the ASHOE campaign. However, $\mathrm{NO}_{y}$ inside the vortex cannot be derived directly from the $\mathrm{CH}_{4} / \mathrm{NO}_{y}$ ER-2 correlation in this case, since denitrification has taken place in the vortex during the preceding cold period and the ER-2 measurements of $\mathrm{CH}_{4}$ and $\mathrm{NO}_{\mathrm{y}}$ were located outside the vortex. A rough approximation of the denitrification inside the vortex is an average $\mathrm{NO}_{\mathrm{y}}$ reduction by $75 \%$ of the outsidevortex value, as observed in 1987 by Fahey et al. [1990]. Minimum temperatures in the 1987 and 1994 winters were similarly low, about $182 \mathrm{~K}$ in July, and also the observed minimum $\mathrm{H}_{2} \mathrm{O}$ mixing ratios of $1.5-2 \mathrm{ppmv}$ were comparable with those of 1987 [Kelly et al., 1989]. This estimate of $75 \%$ denitrification was used to initialize $\mathrm{HNO}_{3}$ and the other unknown $\mathrm{NO}_{y}$ species inside the vortex. The relative partitioning between the unknown $\mathrm{NO}_{\mathrm{y}}$ species was taken from the 2-D model. The sensitivity of the model results to this approximation is discussed below.

Radicals with short lifetimes such as $\mathrm{O}, \mathrm{O}\left({ }^{1} \mathrm{D}\right), \mathrm{OH}, \mathrm{HO}_{2}$, $\mathrm{Cl}$ and $\mathrm{Br}$ were initialized with zero mixing ratio. This is justified since they adjust themselves to photochemical equilibrium with other species on short timescales, so their initialization does not significantly affect the model calculations. Total inorganic bromine $\mathrm{Br}_{\mathrm{x}}$ was taken from the 2-D model. It was initialized as $\mathrm{BrO}$ because it undergoes fast redistribution within the $\mathrm{Br}_{\mathrm{x}}$ family. All other chemical species that have minor importance and minor variability were initialized directly from the output of the 2-D model.

The overhead ozone profile that is needed for the calculation of radiative fluxes was held constant along the trajectory and was determined from the HALOE ozone profile at the beginning of the calculation. The method of initializing the model with HALOE data was tested in comparison with in situ measurements from the ER-2 aircraft and was shown to be successful [Pierce et al., this issue]. Due to the long lifetime and narrow data range of the $\mathrm{HCl}$ in middle latitudes, the predicted $\mathrm{HCl}$ by the HALOE initialized trajectories did not compare with the ER-2 data as well as the other species; a mean bias of $0.09 \mathrm{ppbv}$ was found. This is, however, of minor relevance to this study, since the variability of $\mathrm{HCl}$ inside the polar vortex was much larger and a small mean bias in the $\mathrm{HCl}$ data does not contribute to the calculated increase rates.

\section{Results}

The calculations show an increase of $\mathrm{HCl}$ in almost all trajectories from the low initial mixing ratios resulting from earlier chlorine activation to values close to total inorganic chlorine in some cases, consistent with the HALOE $\mathrm{HCl}$ observations. Figure 3 displays the development in time of the key chemical species $\mathrm{O}_{3}, \mathrm{HCl}, \mathrm{ClONO}_{2}, \mathrm{ClO}, \mathrm{HOCl}$ and $\mathrm{NO}_{x}$ for a typical trajectory calculation inside the polar vortex. The $\mathrm{HCl}$ mixing ratio increases up to a maximum possible $2.7 \mathrm{ppbv}\left(=\mathrm{Cl}_{\mathrm{y}}\right.$, derived from HALOE HF data) at the end of the trajectory. The trajectory starts with a low ozone mixing ratio of 0.53 ppmv resulting from catalytic destruction in the ozone hole. It has a high initial $\mathrm{ClONO}_{2}$ mixing ratio and a low $\mathrm{ClO}$ mixing ratio derived from the 2-D model partitioning of ClOX.

$\mathrm{ClO}$ is produced during daytime by $\mathrm{ClONO}_{2}$ photolysis. During nighttime, $\mathrm{ClONO}_{2}$ is formed due to recombination with $\mathrm{NO}_{2}$. The conversion of $\mathrm{ClOX}$ species into $\mathrm{HCl}$ during the modeled time is clearly seen in the simultaneous $\mathrm{ClONO}_{2}$ decrease and $\mathrm{HCl}$ increase. The decomposition of $\mathrm{ClONO}_{2}$ also causes an increase in $\mathrm{NO}_{\mathrm{x}}$ mixing ratios.

Due to low water vapor mixing ratios and higher temperatures, none of the trajectories in this study reached temperatures below the ice frost point $\left(T_{\text {ice }}=183.3 \mathrm{~K}(185.6 \mathrm{~K})\right.$ for $50 \mathrm{hPa}$ and $2.0(3.0) \mathrm{ppmv} \mathrm{H}_{2} \mathrm{O}$ ), which are needed to form crystalline PSC particles (ice, NAT, SAT). However, heterogeneous chemistry on the ternary liquid aerosol is still important in some trajectories. In this example, a minor heterogeneous reactivation of chlorine on day 4 (September 28 ) is calculated at temperatures around $188 \mathrm{~K}$. For the given gas phase mixing ratios in this example (1.9 ppmv $\mathrm{H}_{2} \mathrm{O}, 1.7$ ppbv $\mathrm{HNO}_{3}$ ), the typical lifetime of $\mathrm{HCl}$ due to the fastest of the heterogeneous reactions, $\mathrm{HCl}+\mathrm{ClONO}_{2}$, is about 2 days at the minimum temperature $T=188 \mathrm{~K}$. This is not sufficient for a complete activation of chlorine. (A higher $\mathrm{H}_{2} \mathrm{O}$ mixing ratio of $3 \mathrm{ppmv}$ would decrease this lifetime by a factor 2.5.)

Very few of the trajectories show a further period of significant chlorine activation due to heterogeneous reactions on the liquid aerosols at this late period in the spring. Only two of the 63 trajectories got near the south pole, where there are low temperatures and continuous sunlit conditions. These conditions are suitable for the heterogeneous reaction $\mathrm{ClONO}_{2}+\mathrm{HCl} \rightarrow \mathrm{Cl}_{2}+\mathrm{HNO}_{3}$ on liquid ternary aerosol particles, and lead to a complete removal of $\mathrm{HCl}$ in these two trajectories. Despite these two exceptions, all other trajectories undergo only minor heterogeneous chlorine activation, such as on day 4 of Figure 3. The chlorine deactivation and a fast recovery of $\mathrm{HCl}$ during late September and early October dominate the photochemistry of the vortex airmasses considered.

In the absence of heterogeneous chlorine activation reactions, the $\mathrm{HCl}$ increase rate, $d[\mathrm{HCl}] / d t$, is determined mainly by

$$
\mathrm{Cl}+\mathrm{CH}_{4} \rightarrow \mathrm{HCl}+\mathrm{CH}_{3} \text {. }
$$

Other standard $\mathrm{HCl}$-yielding reactions have a much smaller contribution to the $\mathrm{HCl}$ production. The time derivative of the $\mathrm{HCl}$ concentration due to this reaction is given by

$$
\frac{d}{d t}[\mathrm{HCl}]=k_{1} \cdot\left[\mathrm{CH}_{4}\right] \cdot[\mathrm{Cl}]
$$

where $k_{1}$ is the rate of reaction ( $\mathrm{R} 1$ ). Thus, the $\mathrm{HCl}$ recovery is governed by the chlorine atom concentration, which itself is determined by its main production reaction

$$
\mathrm{ClO}+\mathrm{NO} \rightarrow \mathrm{Cl}+\mathrm{NO}_{2}
$$



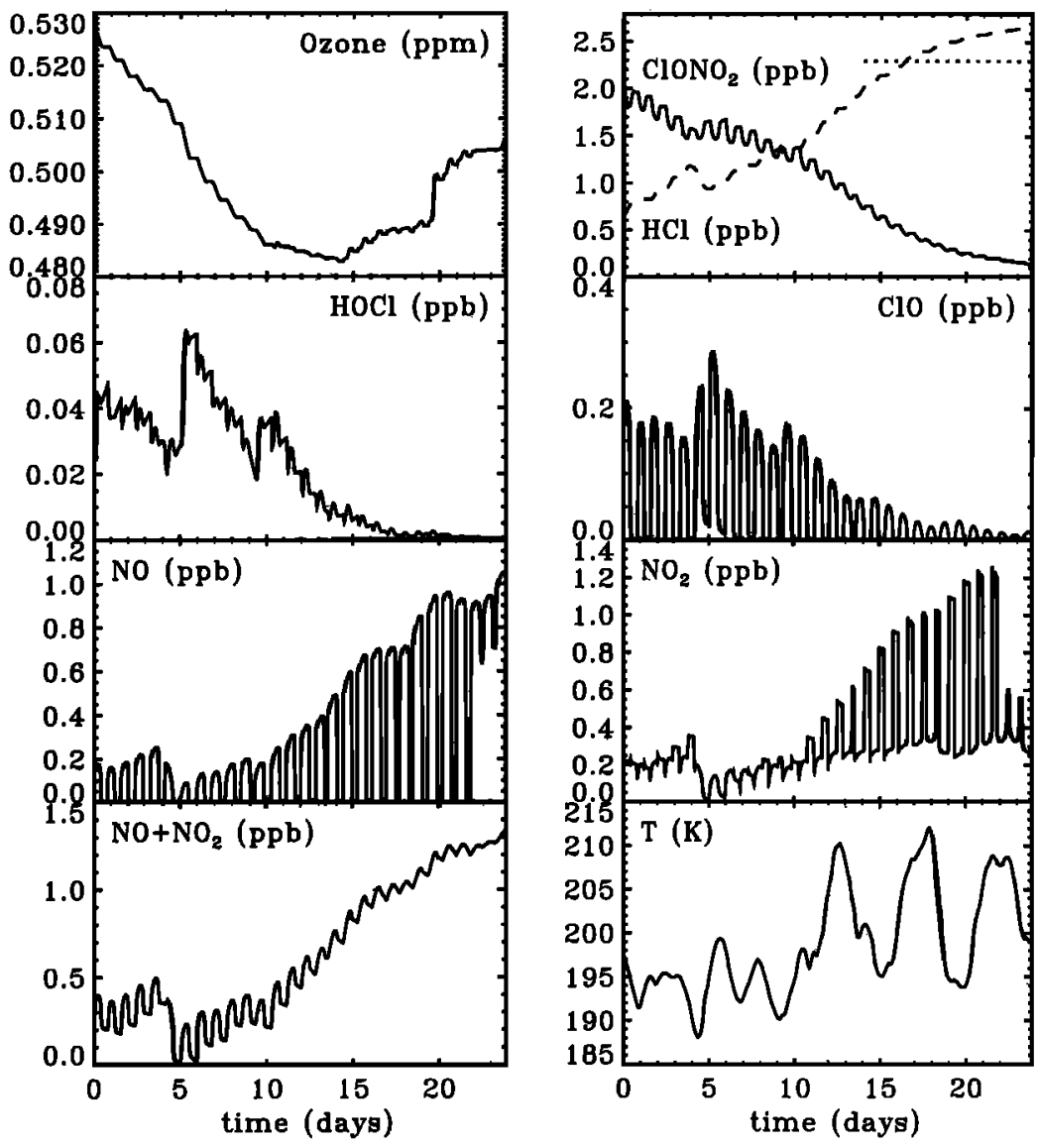

Figure 3. Development of the key chemical species of one example trajectory on the $460 \mathrm{~K}$ isentropic surface. The trajectory starts on September 24,1994 , at $67^{\circ} \mathrm{S}$. The modeled airmass is strongly dehydrated $\left(\mathrm{H}_{2} \mathrm{O}=1.9 \mathrm{ppmv}\right)$ and considered denitrified $\left(\mathrm{HNO}_{3}=1.7 \mathrm{ppbv}\right)$. The $\mathrm{CH}_{4}$ mixing ratio is $0.86 \mathrm{ppmv}$. The dotted line in the $\mathrm{HCl}$ panel corresponds to the $2.3 \mathrm{ppbv}$ level $\left(85 \%\right.$ of $\left.\mathrm{Cl}_{\mathrm{y}}\right)$, up to which the $\mathrm{HCl}$ increase rates contribute to the calculated average (see text).

and the sink reaction

$$
\mathrm{Cl}+\mathrm{O}_{3} \rightarrow \mathrm{ClO}+\mathrm{O}_{2} .
$$

Thus, the chlorine atom concentration is given by

$$
[\mathrm{Cl}]=\frac{k_{2}[\mathrm{NO}]}{k_{3}\left[\mathrm{O}_{3}\right]} \cdot[\mathrm{ClO}]
$$

Lower ozone values shift this ratio toward higher $\mathrm{Cl}$ concentrations due to slower formation of $\mathrm{ClO}$.

The NO concentrations are determined by the available $\mathrm{NO}_{\mathrm{x}}$ and the ratio between $\mathrm{NO}$ and $\mathrm{NO}_{2}$. The $\mathrm{NO}_{\mathrm{x}}$ mixing ratio increases as the $\mathrm{ClONO}_{2}$ reservoir is decomposed, and the ratio between $\mathrm{NO}$ and $\mathrm{NO}_{2}$ is given through a photochemical equilibrium of the reactions (R2) and

$$
\begin{gathered}
\mathrm{NO}_{2}+h \nu \rightarrow \mathrm{NO}+\mathrm{O} \\
\mathrm{NO}+\mathrm{O}_{3} \rightarrow \mathrm{NO}_{2}+\mathrm{O}_{2} .
\end{gathered}
$$

This leads to the equilibrium relation

$$
[\mathrm{NO}]=\frac{J_{4}}{k_{2}[\mathrm{ClO}]+k_{5}\left[\mathrm{O}_{3}\right]} \cdot\left[\mathrm{NO}_{2}\right] \text {. }
$$

Since $[\mathrm{ClO}] \gg[\mathrm{Cl}]$, the $\mathrm{ClO}$ concentration can be determined from the major source and sink reactions. The main $\mathrm{ClO}$ source is the photolysis of $\mathrm{ClONO}_{2}$,

$$
\mathrm{ClONO}_{2}+h \nu \rightarrow \mathrm{Cl}+\mathrm{NO}_{3}
$$

followed by reaction (R3) given above. With the sink reaction

$$
\mathrm{ClO}+\mathrm{NO}_{2}+\mathrm{M} \rightarrow \mathrm{ClONO}_{2}+\mathrm{M},
$$

the steady state $\mathrm{ClO}$ concentration is given approximately by

$$
[\mathrm{ClO}] \approx \frac{J_{6}\left[\mathrm{ClONO}_{2}\right]}{k_{7}\left[\mathrm{NO}_{2}\right]}
$$

A combination of the equations (1) to (4) yields

$$
\frac{d}{d t}[\mathrm{HCl}]=\frac{k_{1} k_{2} J_{4} J_{6}\left[\mathrm{CH}_{4}\right]}{k_{3} k_{7}\left[\mathrm{O}_{3}\right]} \cdot \frac{\left[\mathrm{ClONO}_{2}\right]}{k_{2}[\mathrm{ClO}]+k_{5}\left[\mathrm{O}_{3}\right]}
$$

This equation contains reaction rates, photolysis rates and concentrations of slowly varying compounds $\mathrm{CH}_{4}, \mathrm{ClONO}_{2}$ and $\mathrm{O}_{3}$, as well as the daily variable species $\mathrm{ClO}$. Higher $\mathrm{HCl}$ increase rates are obtained for lower ozone concentra- 
tions. With the increase of $\mathrm{HCl}$, the $\mathrm{ClONO}_{2}$ concentrations decrease since total inorganic chlorine is conserved. For low ozone mixing ratios, $\mathrm{HCl}$ concentrations can increase until saturation in which almost no ClOX is left and all the inorganic chlorine is in the form of $\mathrm{HCl}$. The photolysis rates $J_{4}$ and $J_{6}$ in the numerator indicate that $\mathrm{HCl}$ recovery only takes place during sunlit hours.

To compare the results with the HALOE observations of Figure 2, the average $\mathrm{HCl}$ increase rates $\overline{d[\mathrm{HCl}] / d t}$ are computed for all calculated vortex trajectories. In the trajectories starting with the lowest ozone mixing ratios, the $\mathrm{HCl}$ mixing ratio increases fast toward its maximum possible value, about $2.7 \mathrm{ppbv}$, and stays constant at this level over the remaining time of the trajectory. To look only at the periods of increasing $\mathrm{HCl}$ mixing ratios, the average of the $\mathrm{HCl}$ increase rate was taken over the time in which $\mathrm{HCl}$ is below $85 \%$ of the maximal value. This value ( $2.3 \mathrm{ppbv})$ is marked in the $\mathrm{HCl}$ panel of Figure 3 by a dotted line.

In Figure 4 the mean $\mathrm{HCl}$ increase rate $\overline{d[\mathrm{HCl}] / d t}$ as a function of initial ozone mixing ratio for the calculated polar trajectories is shown (black circles). It is clearly larger for low ozone concentrations and reaches high values of the order of 0.1 to $1 \mathrm{ppbv} / \mathrm{d}$ for ozone mixing ratios lower than 0.4 ppmv. A few trajectories with slightly negative $\overline{d[\mathrm{HCl}] / d t}$ due to heterogeneous chlorine activation are outside the plotted range.

However, there is a quantitative discrepancy between these calculations and the $\mathrm{HCl}$ increase rate derived from HALOE. The $\mathrm{HCl}$ time derivatives estimated from HALOE (see Figure 2) are plotted by large pluses in Figure 4 . The calculated

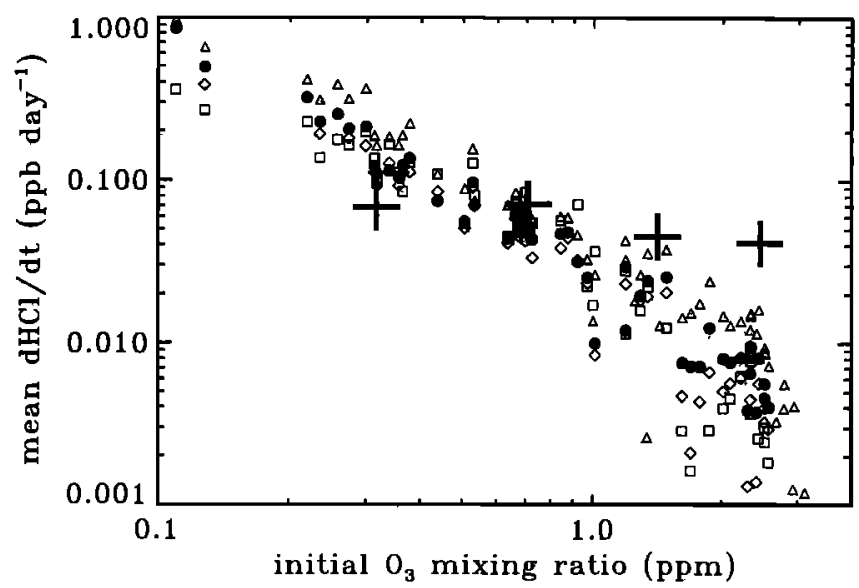

Figure 4. Mean $\mathrm{HCl}$ increase rate as a function of initial ozone mixing ratio for isentropic trajectories on the $\theta=460 \mathrm{~K}$ level starting from September 24 to 29,1994 , inside the polar vortex. The black circles indicate the mean $\mathrm{HCl}$ increase rate of the reference calculation for each single trajectory run. The large pluses correspond to $\mathrm{HCl}$ increase rates derived from HALOE data (see Figure 2). The symbols are the results of the different sensitivity calculations: triangles denote calculations with less denitrification inside the vortex $\left(\mathrm{NO}_{\mathrm{y}}=0.5 \cdot \mathrm{NO}_{\mathrm{y}}{ }^{\star}\right.$ instead of $\left.0.25 \cdot \mathrm{NO}_{\mathrm{y}}{ }^{\star}\right)$; diamonds denote calculations with double sulfuric acid amount; and squares denote calculations with maximum $\mathrm{ClO}$ initialization $(\mathrm{ClO}=\mathrm{ClOX})$.
$\mathrm{HCl}$ increase rate for ozone mixing ratios between 2 and 3 ppmv (corresponding to vortex edge) is lower by a factor of 4 or more compared with the HALOE observations. This discrepancy is subject to further investigation in the following section, in which the sensitivity of the model results to various model input parameters is investigated. In particular, the discrepancy between the model results and the HALOE observations of the $\mathrm{HCl}$ increase rate will be discussed. The $\mathrm{HCl}$ increase rate for very low ozone mixing ratios (below $0.2 \mathrm{ppmv}$ ) cannot be compared to the HALOE observations sufficiently because of limited data sampling.

\section{Sensitivity Studies}

The influence of many model input parameters and assumptions in this calculation was tested. The sensitivity of the calculations to the denitrification assumption, aerosol amount and partitioning within the ClOX species for initialization is described in this section. Furthermore, the influence of the additional $\mathrm{HCl}$-yielding branches of the reactions of $\mathrm{OH}$ and $\mathrm{HO}_{2}$ with $\mathrm{ClO}$ is discussed.

\section{Denitrification}

The denitrification of the polar vortex in Antarctic spring could not be derived from the ASHOE data, but was estimated based upon Antarctic $\mathrm{NO}_{\mathrm{y}}$ measurements in 1987 [Fahey et al., 1990]. The measurements inside the vortex showed an average decrease of $\mathrm{NO}_{\mathrm{y}}$ to about $0.25 \cdot \mathrm{NO}_{\mathrm{y}}{ }^{\star}$, where $\mathrm{NO}_{y}{ }^{\star}$ is the expected $\mathrm{NO}_{\mathrm{y}}$ mixing ratio derived from the outside-vortex $\mathrm{N}_{2} \mathrm{O}$ tracer correlation. Although comparable dehydration was observed in 1987 , the exact denitrification is not clear. In a sensitivity calculation, this factor 0.25 was replaced by 0.5 . This causes an increase in the initialization of $\mathrm{HNO}_{3}$ by more than a factor of 2 , since the species $\mathrm{NO}, \mathrm{NO}_{2}$ and $\mathrm{ClONO}_{2}$ are fixed by the initialization scheme. The results of the example trajectory are displayed in Figure 5 (thick lines/pluses) in comparison with the reference calculation described above.

The higher $\mathrm{NO}_{\mathrm{y}}$ mixing ratios lead to faster chlorine deactivation because of the main part of $\mathrm{NO}_{\mathrm{y}}$ is in the form of $\mathrm{HNO}_{3}$. The higher $\mathrm{HNO}_{3}$ concentration leads to enhanced $\mathrm{NO}_{x}$ production by $\mathrm{HNO}_{3}$ photolysis, which causes an enhanced chlorine atom concentration due to the more effective reaction of $\mathrm{ClO}$ with NO (see equation (2)). The reaction of $\mathrm{ClO}$ with $\mathrm{NO}$ is favored over the reaction of $\mathrm{ClO}$ with $\mathrm{NO}_{2}$, since the $\mathrm{NO} / \mathrm{NO}_{2}$ daytime ratio increases by a factor of about 2-3 due to lower $\mathrm{ClO}$ mixing ratios (compare equation (3)) and, secondly, the reaction $\mathrm{ClO}+\mathrm{NO}$ being 3.5 times faster than the reaction $\mathrm{ClO}+\mathrm{NO}_{2}$ at $50 \mathrm{hPa}$ and $200 \mathrm{~K}$. Thus a faster $\mathrm{HCl}$ increase rate is calculated according to equation (1). This is illustrated in Figure 5: During the first 10 days of this sensitivity calculation, higher chlorine atom concentrations are seen compared with the reference calculation, leading to a faster $\mathrm{HCl}$ increase. At the end of the calculation, lower ClOX concentrations are calculated, because almost all inorganic chlorine is already converted into $\mathrm{HCl}$, and $\mathrm{ClONO}_{2}$ photolysis is less effective. 

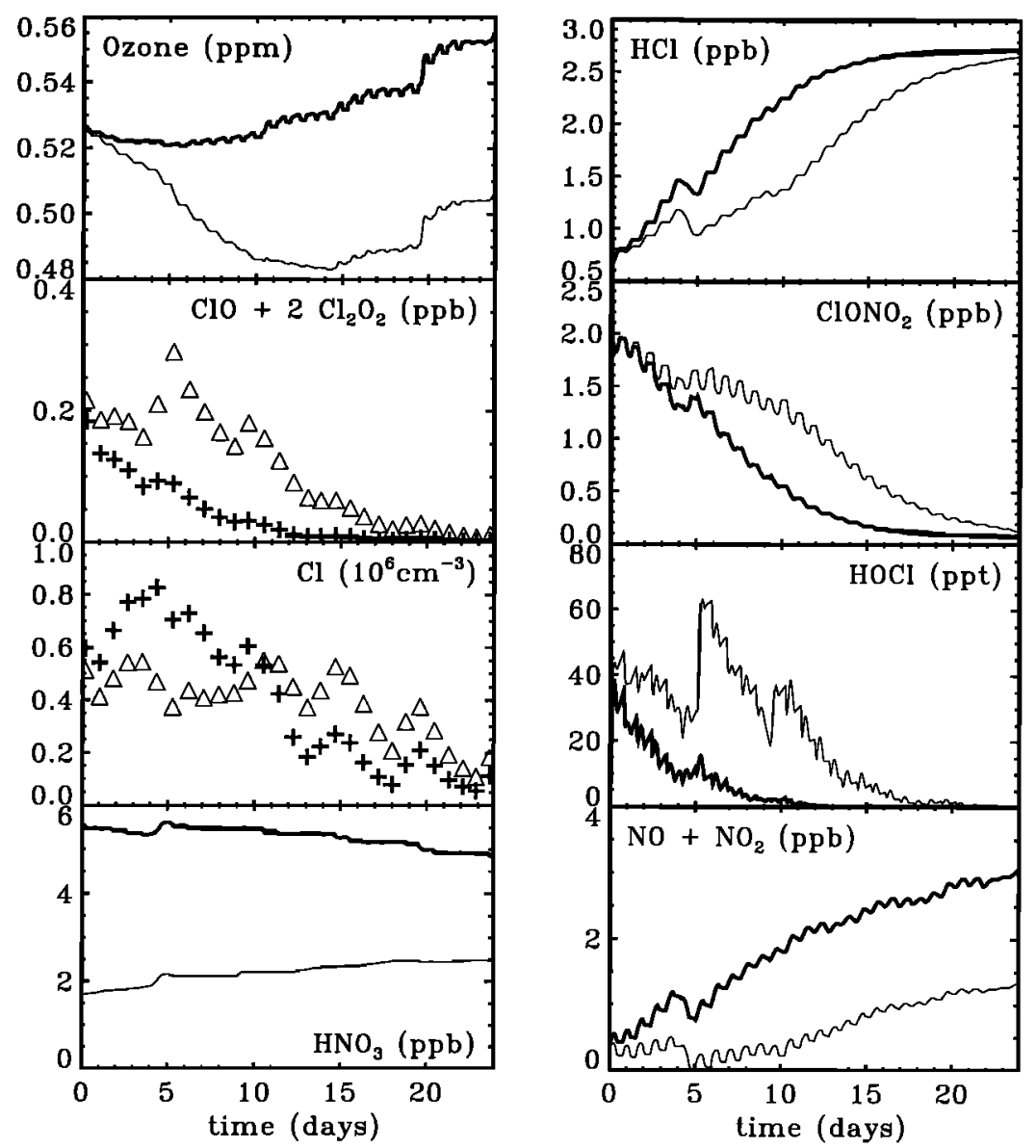

Figure 5. Development of chemical species for the test calculation with enlarged $\mathrm{NO}_{\mathrm{y}}$ (less denitrified air) of the example trajectory on the $460 \mathrm{~K}$ potential temperature surface. Thick lines and pluses correspond to the test calculation and the thin lines and triangles to the reference (shown also in Figure 3). In the plots of the diurnally variable active chlorine species $\left(\mathrm{Cl}, \mathrm{ClO}+2 \cdot \mathrm{Cl}_{2} \mathrm{O}_{2}\right)$, nighttime values are almost zero; therefore only the maximum diurnal values (local noontime) are displayed with a symbol instead of the complete diurnal cycle for better readability.

The $\mathrm{HCl}$ increase rates as a function of ozone mixing ratios for all trajectories of these sensitivity calculations are displayed as triangles in Figure 4. The calculated mean $\mathrm{HCl}$ increase rates are about $50 \%$ higher compared with the reference calculations, but the general behavior in the dependence on ozone mixing ratio does not change. The discrepancy between modeled and observed $\mathrm{HCl}$ increase rates cannot be solved by these calculations. In 1987, the most pronounced observed denitrification was $90 \%$; however, a stronger denitrification would lead to lower $\mathrm{HCl}$ increase rates and is not probable in the vortex edge region.

\section{Liquid Aerosol Abundance}

The results of the calculations are sensitive to the aerosol loading since heterogeneous reaction rates are proportional to the aerosol surface area. The aerosol amount used in the reference calculation $\left(0.25 \mathrm{ppbv}_{2} \mathrm{SO}_{4}\right.$ in the aerosol, particle density $10 \mathrm{~cm}^{-3}$ ) corresponds to background aerosol surface areas of about $1.5 \mu \mathrm{m}^{2} / \mathrm{cm}^{3}$ that are consistent with observed quantities during the ASHOE campaign (J.E. Dye, personal communication, 1996). Heterogeneous chemistry on the sulfate aerosol plays a key role in chlorine activation, and it is important to look for renewed heterogeneous chlorine activation during the deactivation period. A sensitivity calculation was performed by doubling the total $\mathrm{H}_{2} \mathrm{SO}_{4}$ mixing ratio. The results are plotted in Figure 6 for the above example trajectory. In the case of enlarged aerosol amount, more $\mathrm{HCl}$ is converted back into active chlorine, which slows down the mean $\mathrm{HCl}$ increase. The higher $\mathrm{ClO}$ values lead to more ozone destruction through the catalytic chlorine cycles as well as to higher $\mathrm{ClONO}_{2}$ concentrations. Lower $\mathrm{NO}_{\mathrm{x}}$ values are calculated because of an increased reaction rate of $\mathrm{NO}_{2}$ with $\mathrm{ClO}(\mathrm{R} 7)$.

The trajectories show a slower $\mathrm{HCl}$ increase for enlarged aerosol content. The mean $\mathrm{HCl}$ increase rate for all trajectories of this sensitivity calculation is plotted as diamond symbols in Figure 4. For most trajectories, the $\mathrm{HCl}$ increase rate decreases by up to $25 \%$ compared with the standard calculation.

\section{Initial ClOX Partitioning}

As discussed above, there is no information in the HALOE data about the initial partitioning of the ClOX species. In the standard calculation, the ClOX partitioning was taken from 

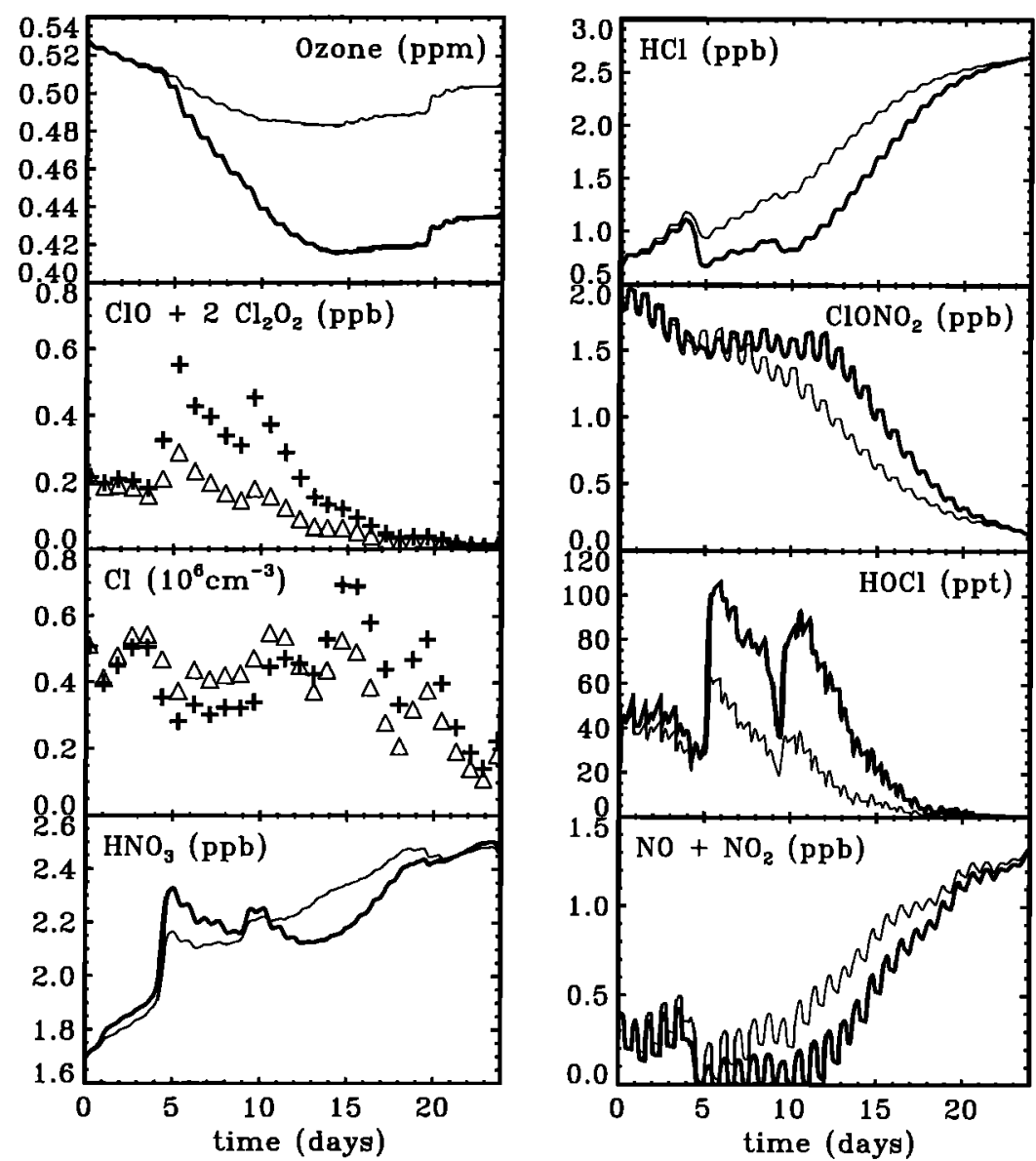

Figure 6. As Figure 5, but for the test calculation with doubled sulfuric acid amount. Note the different scales on the $y$ axis.

the 2-D model output. At the latitudes of the HALOE occultations, from which the trajectories start, the 2-D model predicts almost all ClOX to be in the form of $\mathrm{ClONO}_{2}$, corresponding to conditions on the vortex edge $\left(65^{\circ} \mathrm{S}\right)$. However, it is likely that ClOX is still mostly in the form of active chlorine as the 2-D model output suggests inside the vortex $\left(75^{\circ} \mathrm{S}\right)$. Therefore, the opposite extreme situation was calculated, in which all initial $\mathrm{ClOX}$ was initialized as $\mathrm{ClO}$. Clearly, more ozone destruction is seen in these calculations due to higher concentration of active chlorine that is involved in catalytic destruction of ozone. Figure 7 shows the development of species for the two extreme initial conditions. After about 10 days, $\mathrm{ClO}$ and $\mathrm{ClONO}_{2}$ levels have reached about equal values in both runs. After day 10 , a faster recovery of $\mathrm{HCl}$ is seen in the high $\mathrm{ClO}$ case due to lower ozone mixing ratios. At the beginning of the trajectory, a fast complete titration of the available $\mathrm{NO}_{\mathrm{x}}$ by $\mathrm{ClO}$ yielding $\mathrm{ClONO}_{2}$ takes place.

Both effects compete against each other: In the beginning, higher $\mathrm{ClO}$ mixing ratios cause slower $\mathrm{HCl}$ recovery (see equation (5)), and later, faster $\mathrm{HCl}$ recovery is caused by lower ozone concentrations. The mean $\mathrm{HCl}$ increase rate for all trajectories of this sensitivity calculation is plotted with squares in Figure 4. The higher initial chlorine activation causes changes of $\pm 30 \%$ in the $\mathrm{HCl}$ increase rate.

\section{Heterogeneous Chemistry}

Sensitivity calculations were carried out in which the scheme for heterogeneous chemistry was changed such that NAT particles form at $3 \mathrm{~K}$ below the NAT equilibrium temperature $T_{\mathrm{NAT}}$ [Molina et al., 1993] instead of being only formed as temperatures decrease below the ice frost point. In these calculations, the particles were initially solid (SAT). However, due to denitrification and dehydration, $T_{\mathrm{NAT}}$ is significantly lower than for typical stratospheric $\mathrm{H}_{2} \mathrm{O}$ and $\mathrm{HNO}_{3}$ mixing ratios $\left(T_{\mathrm{NAT}}=189.9 \mathrm{~K}\right.$ for 2 ppmv $\mathrm{H}_{2} \mathrm{O}$ and $2 \mathrm{ppbv} \mathrm{HNO}_{3}$ at $50 \mathrm{hPa}$ [Hanson and Mauersberger, 1988]), and NAT nucleation does not occur in any of the trajectories. Figure 8 shows the calculated $\mathrm{HCl}$ increase rates for the modified microphysics (crosses) and without heterogeneous chemistry (pluses) and for the reference calculation (open circles). The results of the calculation with solid SAT lie between the reference calculation (formation of liquid aerosol at $T>T_{\mathrm{SAT}} \approx 215 \mathrm{~K}$ ) and the calculation without heterogeneous chemistry $\left(T<T_{\mathrm{SAT}}\right)$.

So far, we conclude that the sensitivity of the $\mathrm{HCl}$ increase rate to the uncertain input parameters is small compared with the discrepancy between the model and HALOE data. However, the discrepancy between the observed and calculated $\mathrm{HCl}$ increase rate might be resolved by incorporating the additional reactions described now. 

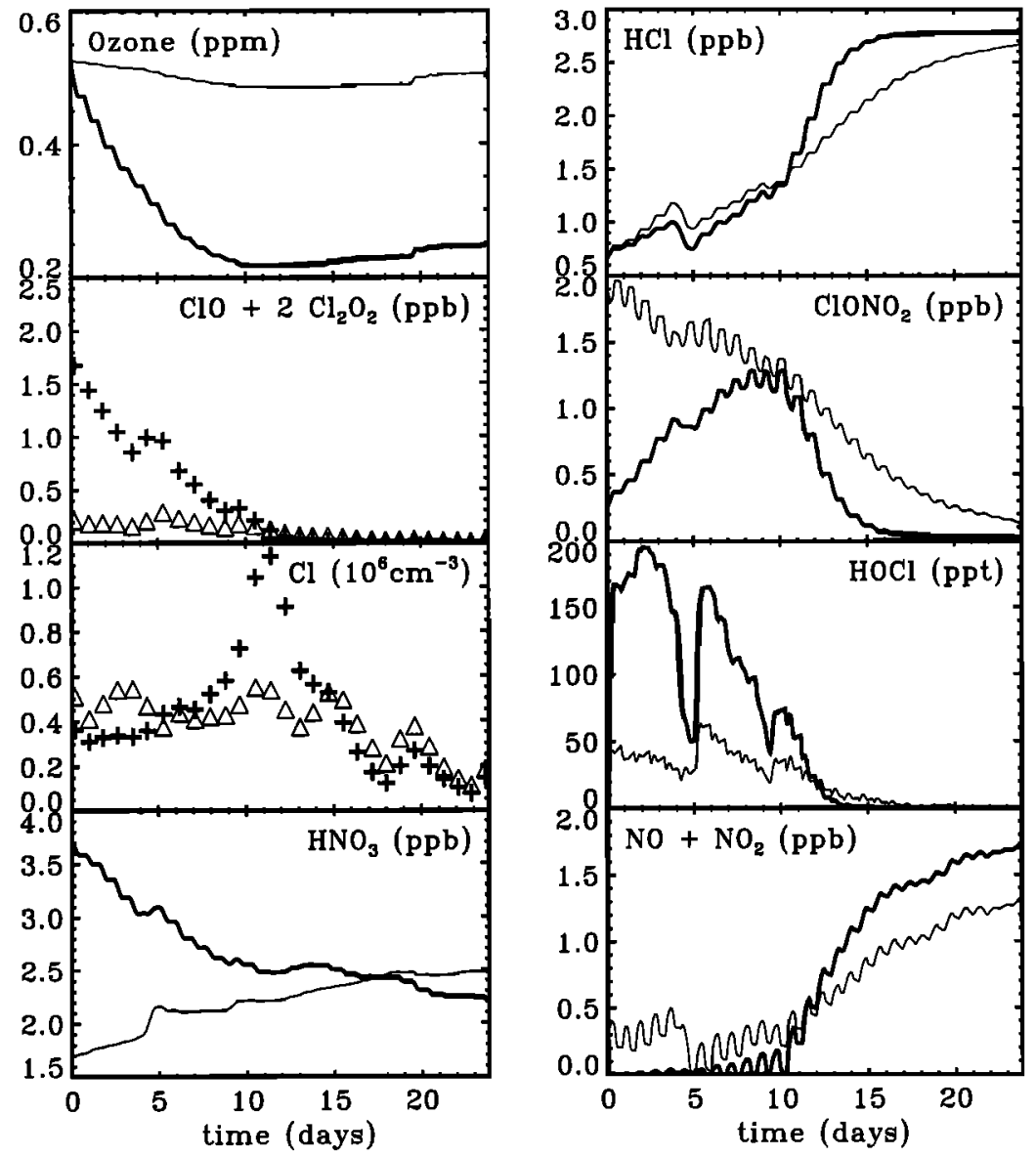

Figure 7. As Figure 5, but for the test calculation with maximum $\mathrm{ClO}$ initialization. The difference in $\mathrm{HNO}_{3}$ initialization is due to conservation of $\mathrm{NO}_{\mathrm{y}}$ and different $\mathrm{ClONO}_{2}$ initialization. Note the different scales on the $y$ axis.

\section{Additional Reaction Branches}

One important result of this study is the calculation of a much lower $\mathrm{HCl}$ increase rate than is derived from the HALOE occultation. This discrepancy could indicate that

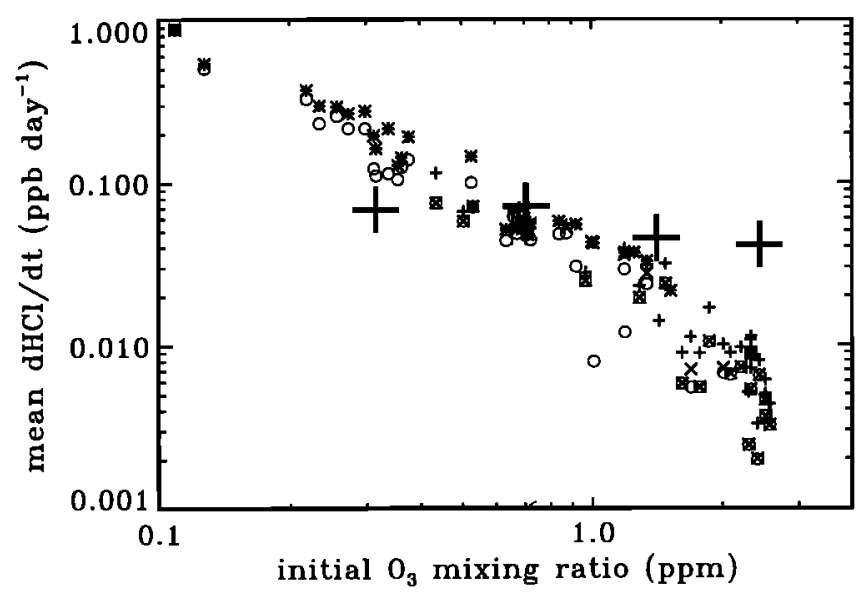

Figure 8. As Figure 4, but for the different assumptions for different microphysics assumptions. Open circles represent the reference calculations with liquid aerosol; also plotted are the results of calculations initialized with crystalline SAT (crosses), and without heterogeneous chemistry (pluses). other reactions are occurring. There are two speculative reaction branches yielding $\mathrm{HCl}$ that are not in the standard box model version:

$$
\begin{aligned}
& \mathrm{ClO}+\mathrm{OH} \rightarrow \mathrm{HCl}+\mathrm{O}_{2} \\
& \mathrm{ClO}+\mathrm{HO}_{2} \rightarrow \mathrm{HCl}+\mathrm{O}_{3}
\end{aligned}
$$

The main products of these two reactions are $\mathrm{Cl}+\mathrm{HO}_{2}$ and $\mathrm{HOCl}+\mathrm{O}_{2}$, but small branching ratios yielding $\mathrm{HCl}$ are possible. The $\mathrm{HCl}$-yielding branching ratios of both reactions are uncertain. Ab initio calculations suggest that the $\mathrm{HCl}$-yielding branching ratio of the reaction $\mathrm{ClO}+\mathrm{OH}$ (R8) is small (but not necessarily zero), because it involves spinforbidden curve crossings [Lee and Rendell, 1993]. Laboratory measurements indicate a branching ratio for this reaction between 0 and 14\% [Poulet et al., 1986; DeMore et al., 1994]. The HCl-yielding branching ratio for the reaction $\mathrm{ClO}+\mathrm{HO}_{2}$ (R9) is dependent on temperature and pressure. At $900 \mathrm{hPa}$ and $210 \mathrm{~K}$, a branching ratio of $5 \pm 2 \%$ was measured, decreasing to $2 \pm 1 \%$ at $240 \mathrm{~K}$ [Finkbeiner et al., 1995]. A few measurements are also available at low temperature and low pressure. These measurements were made in a helium atmosphere with about $3 \mathrm{hPa}$ pressure, corresponding to an atmospheric pressure of $0.5 \mathrm{hPa}$. An upper 
limit of 3\% at $248 \mathrm{~K}[\mathrm{Leu}, 1980]$ and an upper limit of $1 \%$ at $215 \mathrm{~K}$ ( J. Crowley, unpublished results, 1995) were observed. In the intermediate pressure range between $\approx 0.5$ and $900 \mathrm{hPa}$ and at temperatures below $210 \mathrm{~K}$, no measurements of the $\mathrm{HCl}$-yielding branching ratio of $\mathrm{ClO}+\mathrm{HO}_{2}$ are reported. Therefore the pressure and temperature dependence of this branching ratio in the stratosphere is still unclear.

The importance to ozone in the middle stratosphere of a possible branch of the reaction between $\mathrm{ClO}$ and $\mathrm{OH}$ yielding $\mathrm{HCl}(\mathrm{R} 8)$ has been already discussed [Brïhl and Crutzen, 1988; McElroy and Salawitch, 1989; Toumi and Bekki, 1993; Eckman et al., 1995]. The incorporation of this reaction branch of the order of $5 \%$ improves agreement between model calculations and observations. Lary et al. [1995] show that incorporation of reaction (R8) into photochemical models causes a faster $\mathrm{HCl}$ recovery in the lower stratosphere. A detailed analysis based on simultaneously observed $\mathrm{HO}_{\mathrm{x}}, \mathrm{NO}_{\mathrm{x}}$ and chlorine species between 20 and $40 \mathrm{~km}$ [Chance et al., 1996] concluded that a small $\mathrm{HCl}-$ yielding branching ratio for the reaction of $\mathrm{ClO}$ with $\mathrm{HO}_{2}$ or $\mathrm{OH}$ is needed to bring the photochemical model calculations into agreement with the HALOE data. In that study, a branching ratio of $5 \%$ for reaction (R8) and $3 \%$ for reaction (R9) gives the best agreement between the observations and the model which is used here. Sensitivity calculations were performed in which the two reaction branches with the quoted branching ratios were added.

For this analysis the initialization of the ClOX species plays an important role, because the rate of $\mathrm{HCl}$ increase due to the reactions (R8) and (R9) depends on the $\mathrm{ClO}$ concentration. With these additional reaction branches, calculations were performed with the two extreme cases of initial ClOX partitioning as discussed before. The results of these calculations are shown in Figure 9 for both initial ClOX partitionings. For ozone mixing ratios above $1 \mathrm{ppmv}$, the calculated $\mathrm{HCl}$ increase is substantially faster compared with the reference calculation. The discrepancy between HALOE observations and the calculations for high ozone mixing ratios is much lower, but there are still differences. In the calculation with the initialization of high chlorine activation, the higher $\mathrm{ClO}$ concentrations cause a higher efficiency of the reactions (R8) and (R9). Therefore, an even faster increase of the $\mathrm{HCl}$ mixing ratios is seen, which gives the best agreement of all sensitivity calculations. However, the calculated $\mathrm{HCl}$ increase rates in both cases are still lower than the HALOE observations. This suggests that reactions (R8) and (R9) may indeed take place in the stratosphere and might even have larger partitionings than used here. A more exact determination of the branching ratios by laboratory measurements would reduce this uncertainty in model calculations.

There may also be other error sources which could cause part of the discrepancy. For example, the uncertainty of model input parameters as reaction rate coefficients influences the results. The reported uncertainties in $k_{1}\left(\mathrm{CH}_{4}+\mathrm{Cl}\right)$ and $k_{2}(\mathrm{NO}+\mathrm{ClO})$ at $200 \mathrm{~K}$ are $40 \%$ and $35 \%$, respectively [DeMore et al., 1994]; an increase of these rate coefficients to their maximum possible values could cause about $90 \%$ increase in the $\mathrm{HCl}$ increase rate (see equation (5)) and also

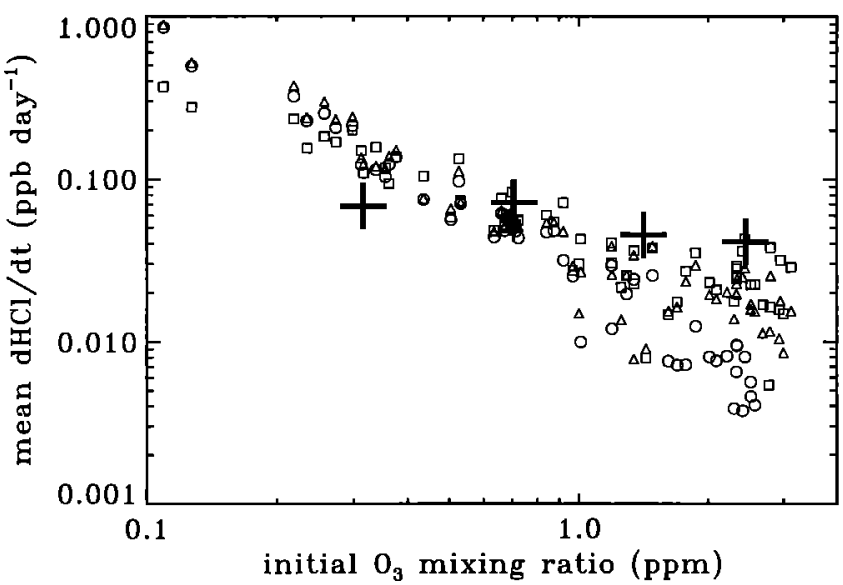

Figure 9. Mean $\mathrm{HCl}$ increase rate as a function of initial ozone mixing ratio with the additional reactions (R8) and (R9). The open circles indicate the mean $\mathrm{HCl}$ increase rate obtained by the reference calculation. The symbols are the results from the calculation with the branching ratios of $5 \%$ and $3 \%$ for the reactions (R8) and (R9). Large pluses correspond to the increase rate derived from the HALOE data. The calculations were performed with two different initial ClOX partitionings. Triangles denote ClOX partitioning from 2-D model $\left(92 \% \mathrm{ClONO}_{2}, 8 \% \mathrm{ClO}\right)$ as in the reference run. Squares denote initialization with all $\mathrm{ClOX}$ set to $\mathrm{ClO}$.

reduce the discrepancy. Similar consideration applies for a decrease in the reaction rates $k_{3}\left(\mathrm{Cl}+\mathrm{O}_{3}, 35 \%\right)$ and $k_{7}$ $\left(\mathrm{ClO}+\mathrm{NO}_{2}, 35 \%\right)$. Together with the estimated uncertainty of 30-40\% from the HALOE observations, most of the discrepancy at the vortex edge could also be explained without reactions (R8) and (R9), if these rate coefficients were assigned to their extreme possible values simultaneously. However, this case seems rather unlikely and may cause discrepancies for lower ozone mixing ratios, where in the current study reasonable agreement was found.

\section{Summary}

Calculations with the linked NASA Langley Research Center trajectory model and Mainz photochemical box model for a large set of trajectories in the Antarctic region have been presented. A method to derive the chemical initialization of box model calculations on the basis of HALOE data was introduced. The calculations were used to analyze stratospheric chemistry changes in the polar vortex at the end of the period of heterogeneous chlorine activation and chlorinecatalyzed ozone destruction; in particular, the observations and calculations of the $\mathrm{HCl}$ recovery were studied. The $\mathrm{HCl}$ increase rates depend on the ozone mixing ratios, with faster $\mathrm{HCl}$ increase at lower ozone mixing ratios. $\mathrm{High} \mathrm{HCl}$ increase rates of more than $0.1 \mathrm{ppbv} / \mathrm{d}$ were found for ozone mixing ratios below $0.5 \mathrm{ppmv}$. A complete conversion of all available $\mathrm{ClOX}$ into $\mathrm{HCl}$ is seen in both the box model calculations and the HALOE observations. For ozone mixing ratios above 1 ppmv a quantitative discrepancy of the $\mathrm{HCl}$ increase rate between calculations and HALOE observations was found. The sensitivity of the box model results to the 
assumption of denitrification, to the sulfate aerosol amount, and to the ClOX initialization was investigated. None of the three could (completely) explain the discrepancy in $\mathrm{HCl}$ increase rate for high ozone mixing ratios. The discrepancy may be resolved by $\mathrm{HCl}$-yielding branches in the reactions of $\mathrm{OH}$ and $\mathrm{HO}_{2}$ with $\mathrm{ClO}$.

Acknowledgments. The authors thank Kenneth S. Carslaw, Christoph Brühl and John Crowley for fruitful discussions, the latter also for providing unpublished results. Kenneth Carslaw provided the box model module for heterogeneous chemistry on supercooled ternary liquid particles, David Lary the photolysis module; Rolf Müller and Thomas Peter developed the main part of the model. We also acknowledge the ASHOE theoretical team, in particular T. Duncan Fairlie and Gretchen Lingenfelser, for their work during the ASHOE deployments; Terry Davies for providing the UKMO operational forecasts and analyses; and the HALOE data processing team for providing near-real-time HALOE observations during the ASHOE/MAESA deployments.

\section{References}

Brühl, C., and P.J. Crutzen, Scenarios of possible changes in atmospheric temperatures and ozone concentrations due to man's activities, estimated with a one-dimensional coupled photochemical climate model, Clim. Dyn. 2, 173-203, 1988.

Brühl, C., and P.J. Crutzen, MPIC Two-dimensional model, in The Atmospheric Effect of Stratospheric Aircraft, edited by M.J. Prather and E.E. Remsberg, NASA Ref. Publ., 1292, 103-104, 1993.

Brühl, C., S.R. Drayson, J.M. Russell III, P.J. Crutzen, J.M. McInerney, P.N. Purcell, H. Claude, H. Gernandt, T.J. McGee, I.S. McDermid, and M.R. Gunson, Halogen Occultation Experiment ozone channel validation, J. Geophys. Res., 101, 10217-10240, 1996.

Carslaw, K.S., S.L. Clegg, and P. Brimblecombe, A thermodynamic model of the system $\mathrm{HCl}-\mathrm{HNO}_{3}-\mathrm{H}_{2} \mathrm{SO}_{4}-\mathrm{H}_{2} \mathrm{O}$, including solubilities of $\mathrm{HBr}$, from $328 \mathrm{~K}$ to $<200 \mathrm{~K}$, J. Phys. Chem., 99, 11557-11574, 1995a.

Carslaw, K.S., B.P. Luo, and T. Peter, An analytical expression for the composition of aqueous $\mathrm{HNO}_{3}-\mathrm{H}_{2} \mathrm{SO}_{4}-\mathrm{H}_{2} \mathrm{O}$ stratospheric aerosols including gas phase removal of $\mathrm{HNO}_{3}$, Geophys. Res. Lett., 22, 1877-1880, 1995b.

Chance, K., W.A. Traub, D.G. Johnson, K.W. Jucks, P. Ciarpallini, R.A. Stachnik, R.J. Salawitch, and H.A. Michelsen, Simultaneous measurements of stratospheric $\mathrm{HO}_{\mathrm{x}}, \mathrm{NO}_{\mathrm{x}}$, and $\mathrm{Cl}_{\mathrm{x}}$ : Comparison with a photochemical model, J. Geophys. Res., 101, 9031-9043, 1996.

Crutzen, P.J., R. Müller, C. Brühl, and T. Peter, On the potential importance of the gas phase reaction $\mathrm{CH}_{3} \mathrm{O}_{2}+\mathrm{ClO} \rightarrow \mathrm{ClOO}+$ $\mathrm{CH}_{3} \mathrm{O}$ and the heterogeneous reaction $\mathrm{HOCl}+\mathrm{HCl} \rightarrow \mathrm{H}_{2} \mathrm{O}+$ $\mathrm{Cl}_{2}$ in "ozone hole" chemistry, Geophys. Res. Lett., 19, $1113-$ $1116,1992$.

Curtis, A.R., and W.P. Sweetenham, Facsimile/Checkmat Users Manual, 135 pp, Comput. Sci. and Syst. Div., Harwell Lab., Oxford, England, 1987

DeMore, W.B., et al., Chemical kinetics and photochemical data for use in stratospheric modeling, JPL Publ. 94-26, 273 pp., Jet Propul. Lab., Pasadena, Calif., 1994.

Douglass, A., M.R. Schoeberl, R.S. Stolarski, J.W. Waters, J.M. Russell III, and A.E. Roche, Interhemispheric differences in springtime production of $\mathrm{HCl}$ and $\mathrm{ClONO}_{2}$ in the polar vortices, J. Geophys. Res., 100, 13967-13978, 1995.

Eckman, R.S., W.L. Grose, R.E. Tumer, W.T. Blackshear, J.M. Russell III, L.F. Froidevaux, J.W. Waters, J.B. Kumer, and A.E. Roche, Stratospheric trace constituents simulated by a threedimensional general circulation model: Comparison with UARS data, J. Geophys. Res., 100, 13951-13966, 1995.

Fahey, D.W., K.K. Kelly, S.R. Kawa, A.F. Tuck, M. Loewenstein,
K.R. Chan, and L.E. Heidt, Observations of denitrification and dehydration in the winter polar stratospheres, Nature, 344, 321324, 1990.

Finkbeiner, M., J.N. Crowley, O. Horie, R. Müller, G.K. Moortgat, and P.J. Crutzen, The reaction between $\mathrm{HO}_{2}$ and $\mathrm{ClO}$ : Product formation between $210 \mathrm{~K}$ and $300 \mathrm{~K}$, J. Phys. Chem., 99, 16264$16275,1995$.

Gear, C.W., The automatic integration of ordinary differential equations, Numer. Math. 14, 176-179, 1971.

Gidel, L.T., P.J. Crutzen, and J. Fishman, A two-dimensional photochemical model of the atmosphere, 1, Chlorocarbon emissions and their effect on stratospheric ozone, J. Geophys. Res., 88, 6622-6640, 1983.

Grooss, J.U., T. Peter, C. Brühl, and P.J. Crutzen, The influence of high flying aircraft on polar heterogeneous chemistry Proceedings of the International Scientific Colloquium, DLR Mitteil., 9406, 229, 1994.

Hanson, D.R., and K. Mauersberger, Laboratory studies of the nitric acid trihydrate: Implications for the south polar stratosphere, Geophys. Res. Lett., 15, 855-858, 1988.

Kelly, K.K., et al., Dehydration in the lower Antarctic stratosphere during late winter and early spring, 1987, J. Geophys. Res., 94, $11317-11357,1989$.

Koop, T., U.M. Biermann, W. Raber, B.P. Luo, P.J. Crutzen, and T. Peter, Do stratospheric aerosol droplets freeze above the ice frost point?, Geophys. Res. Lett., 22, 917-920, 1995.

Lary, D.J., and J.A. Pyle, Diffusive radiation, twilight and photochemistry, J. Atmos. Chem., 13, 373-406, 1991.

Lary, D.J., M.P. Chipperfield, and R. Toumi, The potential impact of the reaction $\mathrm{OH}+\mathrm{ClO} \rightarrow \mathrm{HCl}+\mathrm{O}_{2}$ on polar ozone photochemistry, J. Atmos. Chem., 21, 61-79, 1995.

Lee, T.J., and A.P. Rendell, Ab initio characterization of $\mathrm{ClOOH}$ : Implications for atmospheric chemistry, J. Phys. Chem., 97. 6999-7002, 1993.

Leu, M.-T., Product distribution for the reaction of $\mathrm{HO}_{2}$ with $\mathrm{ClO}$, Geophys. Res. Lett., 7, 173-175, 1980.

McElroy, M.B., and R.J. Salawitch, Changing composition of the global stratosphere, Science, 243, 763-770, 1989.

Molina, M.J., R. Zhang, P.J. Wooldridge, J.R. McMahon, J.E. Kim, H.Y. Chang, and K.D. Beyer, Physical chemistry of the $\mathrm{H}_{2} \mathrm{SO}_{4} / \mathrm{HNO}_{3} / \mathrm{H}_{2} \mathrm{O}$ system: Implications for polar stratospheric clouds, Science, 261, 1418-1423, 1993.

Müller, R., and P.J. Crutzen, A possible role of galactic cosmic rays in chlorine activation during polar night, J. Geophys. Res., 98, 20483-20490, 1993.

Müller, R., T. Peter, P.J. Crutzen, H. Oelhaf, G.P. Adrian, Th. v. Clarmann, A. Wegner, U. Schmidt, and D. Lary, Chlorine chemistry and the potential for ozone depletion in the Arctic stratosphere in the winter of 1991/92, Geophys. Res. Lett., 21, 14271430, 1994.

Müller, R., P.J. Crutzen, J.U. Grooss, C. Brühl, J.M. Russell III, and A.F. Tuck, Chlorine activation and ozone depletion in the Arctic vortex: Observations by the Halogen Occultation Experiment on the Upper Atmosphere Research Satellite, J. Geophys. Res., 101, 12531-12554, 1996.

Pierce, R.B., W.L. Grose, J.M. Russell III, and A.F. Tuck, Evolution of southem hemisphere spring air masses observed by HALOE, Geophys. Res. Lett., 21, 213-216, 1994.

Pierce, R.B., J.U. Grooss, W.L. Grose, J.M. Russell III, P.J. Crutzen, T.D. Fairlie, and G. Lingenfelser, Photochemical calculation along airmass trajectories during ASHOE/MAESA, J. Geophys. Res., this issue.

Poulet, G., G. Laverdet, and G. LeBras, Rate constant and branching ratio for the reaction of $\mathrm{OH}$ with $\mathrm{ClO}, J$. Phys. Chem., 90, 159-165, 1986.

Prather, M., and A.H. Jaffe, Global impact of the Antarctic ozone hole: Chemical Propagation, J. Geophys. Res., 95, 3473-3492, 1990.

Ravishankara, A.R., and D.R. Hanson, Differences in the reactivity 
of type I polar stratospheric clouds depending on their phase, $J$. Geophys. Res., 101, 3885-3890, 1996.

Russell, J.M., III, L.L. Gordley, J.H. Park, S.R. Drayson, W.D. Hesketh, R.J. Cicerone, A.F. Tuck, J.E. Frederick, J.E. Harries, and P.J. Crutzen, The Halogen Occultation Experiment, J. Geophys. Res., 98, 10777-10797, 1993a.

Russell, J.M., III, A.F. Tuck, L.L. Gordley, J.H. Park, S.R. Drayson, J.E. Harries, R.J. Cicerone, and P.J. Crutzen, HALOE Antarctic observations in the Spring of 1991, Geophys. Res. Lett., 20,719$722,1993 \mathrm{~b}$.

Russell, J.M., III, L.E. Deaver, M. Luo, J.H. Park, L.L. Gordley, A.F. Tuck, G.C. Toon, M.R. Gunson, W.A. Traub, D.G. Johnson, K.W. Jucks, D.G. Murcray, R. Zander, I.G. Nolt, and C.R. Webster, Validation of hydrogen chloride measurements made by the Halogen Occultation Experiment from the UARS platform, $J$. Geophys. Res., 101, 10151-10162, 1996.

Shine, K.P., The middle atmosphere in the absence of dynamical heat fluxes, $Q$. J. R. Meteorol. Soc., 113, 603-633, 1987.

Toon, O.B., C.B. Farmer, L.L. Lowes, P.W. Schaper, J.-F. Blavier, and R.H. Norton, Infrared aircraft measurements of stratospheric composition over Antarctica during September 1987, J. Geophys. Res., 94, 16571-16596, 1989.

Toumi, R., and S. Bekki, The importance of the reactions between $\mathrm{OH}$ and $\mathrm{ClO}$ for stratospheric ozone, Geophys. Res. Lett., 20 , 2447-2450, 1993.

J. U. Grooss, ICG-1, Forschungszentrum Jülich, 52425 Jülich, Germany. (e-mail: j.-u.grooss@fz-juelich.de)

W. L. Grose and R. B. Pierce, NASA Langley Research Center, MS 401B, Hampton, VA 23681. (e-mail: grose@haloe.larc.nasa. gov; pierce@kelvin.larc.nasa.gov)

P. J. Crutzen, Max-Planck-Institut für Chemie, P.O. Box 3060, 55020 Mainz, Germany. (e-mail: air@mpch-mainz.mpg.de)

J. M. Russell III, Department of Physics, Hampton University, Hampton, VA 23668. (e-mail: russell@gprc.hamptonu.edu)

(Received May 9, 1996; revised October 28, 1996; accepted October 28, 1996.) 